\title{
TAXONOMIC POTENTIAL OF THE CHEMICAL CONSTITUENTS IN THE CEPHALIC MARKING SECRETIONS OF BOMBUS AND PSITHYRUS SPECIES (HYMENOPTERA, APIDAE) : A NUMERICAL TAXONOMIC STUDY
}

\author{
Xavier BELLÉS * Alcgría GALOFRÉ ** and Antonio GINEBREDA *** \\ * Departamento de Química Orgánica Biológica (C.I.D., C.S.I.C.), \\ J. Girona Salgado 18, 08034 Barcelona, Spain \\ ** Passeig Bonanova 75, 08017 Barcelona, Spain \\ *** Sección de Química Cuántica, Departamento de Quimiometría, \\ Instituto Químico de Sarriá, 08017 Barcelona, Spain
}

\section{SUMMARY}

A tentative study of the chemotaxonomic potential of the cephalic marking secretions of Bombus and Psithyrus specics is presented, using numerical taxonomy methods. Thirty one chemical compounds previously reported by other authors were used as taxonomic characters for a sample of 13 species of Bombus and 6 of Psithyrus. The specics of these two genera appeared mixed in those dendrograms which include the whole sample, thus suggesting a selection of Psithyrus for similarity to Bombus in order to improve their ability for parasitization, rather than phyletic relationships between both genera.

Cluster analysis of Bombus specics showed a quite clean discrimination between the two classical sections Odontobombus and Anodontobombus and, in some cases, the results were consistent with classical classification at lower levels, for example, in the species of the Terrestribombus group.

\section{INTRODUCTION}

The classification, systematics and evolutionary relationships of bumblebees (Bombus) and their parasitic species of cuckoobumblebees (Psithyrus) have been the object of considerable recent research. Nevertheless, some major questions still remain unresolved (cf. PekKarinen et al., 1979), and additional analysis appears to be necessary.

These problems have been approached using different criteria such as wing venation (Plowright and Stephen, 1973), colour variation (PekKarinen, 1979), enzyme constitution (PekKarinen et al., 1979 ; Pekkarinen, 1979 ; Pamilo et 
al., 1978, 1981, 1984 ; ObReCht and SCHOLL, 1981), mouthpart morphometry (PekKarinen, 1979), etc.

In a recent paper, BLum (1981) drew attention to the possible use of the chemical constituents of the exocrine secretions of eusocial insects as a potential source of taxonomic information. Among other examples, he pointed out the cephalic marking secretion of male Bombus and Psithyrus species as a practical case.

The purpose of the present communication is to assess the extent of Blum's qualitative suggestion on the two cited genera, using numerical taxonomy methods, whose reliability in other areas is well established. Therefore, this study should be regarded as preliminary and part of a more general project concerned with the application of numerical taxonomy to the possible taxonomic value of the chemical composition of insect semiochemicals of related species. These types of studies are, to the best of our knowledge, very scarce (cf. BELLÉs et al., 1985).

The chemical composition of the volatile compounds present in the secretions of the labial gland of male bumblebees has been investigated by KuLLENBERG et al. (1970) for 13 species of the genus Bombus and 6 species of the genus Psithyrus. Almost simultaneously, CalaM (1969) reported a similar study for a smaller sample (4 species of Bombus and 1 species of Psithyrus). The results of both groups were in fairly good agreement.

The Swedish research group has also reported more exhaustive analysis for some species (BERgStröm et al., 1973, 1973 a, 1973 b ; Svensson and BergSтRӧм, 1977, 1979), and the results have been summarized and commented upon by BERGSTRÖM et al. (1981).

\section{MATERIALS AND METHODS}

Operative taxonomic units (O.T.U.'s)

Cluster analysis was based upon the taxonomical and chemical data reported by KuLLENBERG et al. (1970) which cover the most representative sample of the two genera under study, i.e., 13 species of Bombus (one of them divided into two forms) and 6 species of Psithyrus.

Bombus species are listed in table 1, assuming the two classical sections Anodontobombus and Odontobombus ( $c f$. KRUGER, 1917 ; FRISON, 1927), and the system of subgenera proposed by RICHARDS (1968). The species of Psithyrus are (our code number in parenthesis) : barbutellus (Kirby) (15), bohemicus (Seidl) (16), campestris (Panzer) (17), globosus Eversman (18), rupestris (Fabricius) (19), and sylvestris (Lepeletier) (20). 
TABL. 1. - Classification of Bombus species included in the cluster analysis.

\begin{tabular}{|c|c|c|c|}
\hline Section & Subgenus & Species & Code number \\
\hline Anodontobombus & $\begin{array}{l}\text { Cullumanobombus } \\
\text { Pyrobombus } \\
\text { Melanobombus } \\
\text { Kallobombus } \\
\text { Bombus }\end{array}$ & $\begin{array}{l}\text { cullumanus Kirby } \\
\text { hypnorum (Linnaeus) } \\
\text { pratorum (Linnaeus) } \\
\text { lapidarius (Linnaeus) } \\
\text { soroeensis (Fabricius) } \\
\text { lucorum (Linnaeus) « Dark » form } \\
\text { lucorum (Linnaeus) «Blonde » form } \\
\text { patagiatus Nylander } \\
\text { sporadicus Nylander } \\
\text { terrestris (Linnaeus) }\end{array}$ & $\begin{array}{r}1 \\
2 \\
3 \\
4 \\
5 \\
6 \\
7 \\
8 \\
9 \\
10\end{array}$ \\
\hline Odontobombus & $\begin{array}{l}\text { Thoracobombus } \\
\text { Megabombus } \\
\text { Subterraneobombus }\end{array}$ & $\begin{array}{l}\text { agrorum (Fabricius) } \\
\text { muscorum (Linnaeus) } \\
\text { hortorum (Linnaeus) } \\
\text { subterraneus (Linnaeus) }\end{array}$ & $\begin{array}{l}11 \\
12 \\
13 \\
14\end{array}$ \\
\hline
\end{tabular}

\section{Characters}

Chemical constituents in the cephalic marking secretions reported by KULLENBERg et al. (1970) and accounting for the cluster analysis are summarized in table 2. Two slightly different sets of qualitative characters, defined by the presence or absence of each chemical constituent, were used. The first character set is composed of the series of thirty-one compounds originally reported (see table 2 ). The second one is based on the same list, except for the compound hexadecen-1-ol, which is split into three isomers according to the three double bond positional isomers $(7,8-; 9,10-$ and 11,12-hexadecen-1-ol, respectively) reported by KULLENBERG et al. (1970). In this set, Bombus hypnorum and Psithyrus sylvestris are omitted from the O.T.U.'s list since there is no indication in the original reference as to the identity of the specific isomers present in their secretions.

\section{Similarity coefficient}

The widely employed Jaceard coefficient ( $c f$. SOKAL and SNEATH, 1973) has been chosen as similarity measure, because it seems to be the most appropriate for the type of characters utilized. It neglects the similarity duc to a common absence of a particular character on the two O.T.U.'s compared, and, conversely, it takes into account only those simultaneously present in both O.T.U.'s.

The use of other coefficients, which consider the overall matching (either by presence or absence), appcars in this case to be inadequate, as it would lead to a false high degree of similarity between most of the O.T.U. pairs.

\section{Clustering method}

Starting from the dissimilarity matrix, hierarchical classifications or dendrograms have been computed, using the weighted pair-group clustering method ( $c f$. SoKal and SNEath, 1973 ; Cuadras, 1981). 
TABL. 2. - Volatile compounds found in the cephalic marking secretions of male bumblebees and cuckoobumblebees (data from KULlENBERG et al., 1970). The species are numbered according the code indicated in Table 1 (Bombus species : 1-14) and in the text (Psithyrus species : 15-20). The presence or absence of each compound in these species is represented by " 1 " or " 0 ", respectively.

\begin{tabular}{|c|c|c|c|c|c|c|c|c|c|c|c|c|c|c|c|c|c|c|c|c|}
\hline \multirow{2}{*}{ Compounds } & \multicolumn{20}{|c|}{ Species } \\
\hline & 1 & 2 & 3 & 4 & 5 & 6 & 7 & 8 & 9 & 10 & 11 & 12 & 13 & 14 & 15 & 16 & 17 & 18 & 19 & 2 \\
\hline Geraniol & 1 & 0 & 1 & 0 & 0 & 0 & 0 & 0 & 0 & 0 & 0 & 0 & 0 & 0 & 0 & 0 & 0 & 0 & 0 & \\
\hline Citronellol & 0 & 0 & 1 & 0 & 0 & 0 & 0 & 0 & 0 & 0 & 0 & 0 & 0 & 0 & 0 & 1 & 0 & 0 & 0 & \\
\hline Geranyl acetate & 1 & 0 & 1 & 0 & 0 & 0 & 0 & 0 & 0 & 0 & 0 & 0 & 0 & 0 & 0 & 0 & 0 & 0 & 0 & 0 \\
\hline Citronellyl acetate & 0 & 0 & 1 & 0 & 0 & 0 & 0 & 0 & 0 & 0 & 0 & 0 & 0 & 0 & 0 & 0 & 0 & 0 & 0 & \\
\hline all-trans-Farnesol & 0 & 0 & 1 & 0 & 0 & 0 & 0 & 0 & 0 & 0 & 0 & 0 & 1 & 0 & 1 & 0 & 0 & 0 & 0 & 0 \\
\hline (-)-2, 3-Dihidrofarnesol & 0 & 0 & 0 & 0 & 0 & 0 & 0 & 0 & 0 & 1 & 0 & 0 & 0 & 0 & 0 & 0 & 0 & 0 & 0 & \\
\hline all-trans-Farnesyl acetate & 1 & 0 & 1 & 0 & 0 & 0 & 0 & 0 & 0 & 0 & 0 & 0 & 0 & 0 & 1 & 0 & 0 & 0 & 0 & \\
\hline 2, 3-Dihydrofarnesyl acetate & 0 & 0 & 0 & 0 & 0 & 0 & 0 & 0 & 0 & 1 & 0 & 0 & 0 & 0 & 0 & 0 & 0 & 0 & $\mathbf{0}$ & 0 \\
\hline Geranylgeraniol & 1 & 0 & 1 & 0 & 0 & 1 & 0 & 0 & 0 & 0 & 0 & 0 & 1 & 1 & 0 & 0 & 0 & 0 & 0 & U \\
\hline Geranylcitronellol & 0 & 1 & 0 & 0 & 0 & 0 & 0 & 0 & 0 & 1 & 0 & 0 & 0 & 0 & 0 & 0 & 0 & 0 & 1 & 0 \\
\hline Geranylgeranyl acetate & 1 & 1 & 1 & 0 & 1 & 1 & 0 & 0 & 0 & 0 & 0 & 0 & 0 & 0 & 0 & 0 & 0 & 0 & 1 & 0 \\
\hline Tetradecan-1-ol & 0 & 0 & 0 & 1 & 0 & 0 & 0 & 0 & 0 & 0 & 1 & 0 & 0 & 0 & 0 & 0 & 0 & 0 & 1 & 1 \\
\hline Hexadecen-1-ol * & 0 & 1 & 0 & 1 & 0 & 0 & 0 & 0 & 0 & 0 & 1 & 0 & 0 & 0 & 0 & 1 & 0 & 0 & 0 & I \\
\hline Hexadecan-1-ol & 0 & 1 & 1 & 1 & 0 & 0 & 0 & 0 & 0 & 1 & 0 & 0 & 0 & 0 & 0 & 0 & 0 & 1 & 1 & 0 \\
\hline Octadecen-1-ol & 0 & 0 & 0 & 0 & 0 & 0 & 0 & 0 & 0 & 0 & 0 & 1 & 1 & 0 & 0 & 0 & 1 & 1 & 0 & 0 \\
\hline Eicosen-1-ol & 0 & 0 & 0 & 0 & 0 & 0 & 0 & 0 & 0 & 0 & 0 & 0 & 0 & 0 & 0 & 0 & 1 & 0 & 0 & 0 \\
\hline Tetradecyl acetate & 0 & 0 & 0 & 0 & 0 & 0 & 0 & 0 & 1 & 0 & 0 & 0 & 0 & 0 & 0 & 0 & 0 & 0 & 0 & 0 \\
\hline Hexadecyl acetate & 0 & 0 & 0 & 0 & 0 & 0 & 0 & 0 & 1 & 0 & 0 & 0 & 0 & 0 & 0 & 0 & 0 & 0 & 0 & 0 \\
\hline Octadecenyl acetate & 0 & 0 & 0 & 0 & 0 & 0 & 0 & 0 & 0 & 0 & 0 & 1 & 0 & 0 & 0 & 0 & 0 & 0 & 0 & 0 \\
\hline Octadecyl acetate & 0 & 0 & 0 & 0 & 0 & 0 & 0 & 0 & 0 & 0 & 0 & 0 & 0 & 0 & 1 & 0 & 0 & 0 & $\mathbf{0}$ & 0 \\
\hline Eicosyl acetate & 0 & 0 & 0 & 0 & 0 & 1 & 0 & 0 & 0 & 0 & 0 & 0 & 0 & 0 & 0 & 0 & 0 & 0 & 0 & 0 \\
\hline Docosyl acetate & 0 & 0 & 0 & 0 & 0 & 1 & 0 & 0 & 0 & 0 & 0 & 0 & 0 & 0 & 0 & 0 & 0 & 0 & 0 & 0 \\
\hline Ethyl decanoate & 0 & 0 & 0 & 0 & 0 & 1 & 0 & 0 & 0 & 1 & 0 & 0 & 0 & 0 & 0 & 0 & 0 & 0 & 0 & 0 \\
\hline Ethyl dodecanoate & 0 & 0 & 0 & 0 & 0 & 1 & 1 & 1 & 1 & 1 & 0 & 0 & 0 & 0 & 0 & 0 & 0 & 0 & 0 & 0 \\
\hline Ethyl tetradecenoate & 0 & 0 & 0 & 0 & 0 & 0 & 1 & 0 & 0 & 1 & 0 & 0 & 0 & 0 & 0 & 0 & 0 & 1 & 0 & 1 \\
\hline Ethyl hexadecenoate & 0 & 1 & 0 & 0 & 0 & 1 & 1 & 0 & 0 & 0 & 0 & 0 & 0 & 0 & 0 & 0 & 0 & 0 & 0 & 0 \\
\hline Ethyl hexadecadienoate & 0 & 0 & 0 & 1 & 0 & 0 & 0 & 0 & 0 & 0 & 0 & 0 & 0 & 0 & 0 & 0 & 0 & 0 & 0 & 0 \\
\hline Ethyl hexadecatrienoate & 0 & 0 & 0 & 0 & 0 & 1 & 1 & 0 & 0 & 0 & 0 & 0 & 0 & 0 & 0 & 0 & 0 & 0 & 0 & 0 \\
\hline Tetradecanal & 0 & 0 & 0 & 0 & 0 & 0 & 0 & 0 & 1 & 0 & 0 & 0 & 0 & 0 & 0 & 1 & 0 & 1 & 0 & 1 \\
\hline Hexadecanal & 0 & 0 & 0 & 0 & 0 & 0 & 0 & 0 & 0 & 0 & 1 & 0 & 0 & 0 & 0 & 1 & 0 & 0 & 0 & 0 \\
\hline Nonadecene & 0 & 0 & 0 & 0 & 0 & 0 & 0 & 0 & 0 & 0 & 0 & 0 & 1 & 0 & 0 & 0 & 0 & 0 & 0 & 0 \\
\hline
\end{tabular}

* Double bond position. - Bombus agrorum : 7, 8; B. lapidarius : 9, 10; Psithyrus bohemicus : 11, 12. 


\section{RESULTS AND DISCUSSION}

The four dendrograms obtained are depicted in Figs. 1-4. In order to discuss the results more conveniently, we will consider separately dendrograms including the species of Bombus and Psithyrus mixed (Figs. 1-2) and those only including Bombus species (Figs. 3-4).

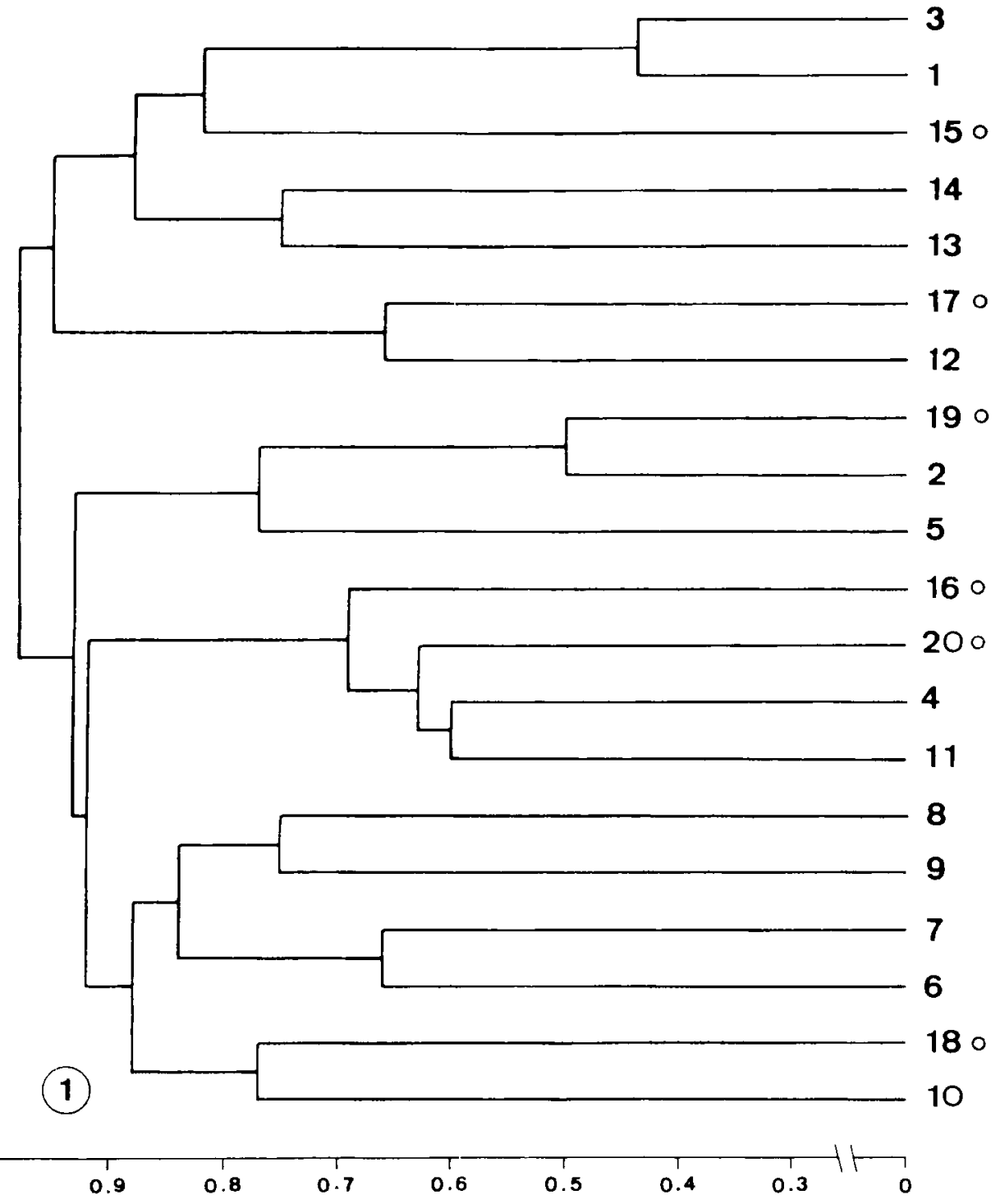

Fig. 1. - Dendrogram obtained for Bombus and Psithyrus species.

(See the code number corresponding to each species in table 1.

Those belonging to the genus Psithyrus are indicated by open circles). 


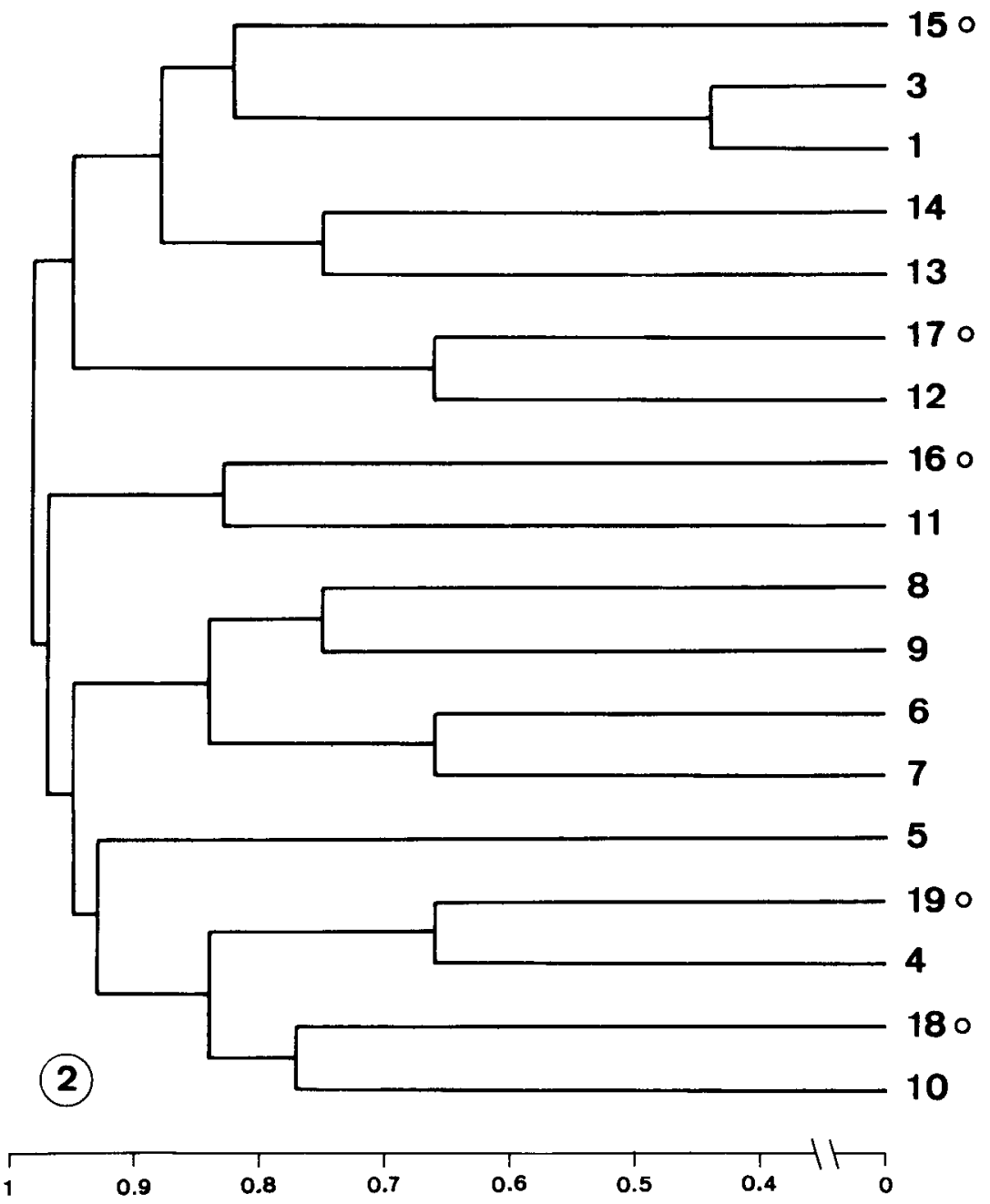

Fig. 2. - Dendrogram obtained for Bombus and Psithyrus species considering the various isomers of hexadecen-1-ol.

(Abbreviations as in figure 1. Bombus hypnorum (2) and Psithyrus sylvestris (20) have been omitted since there is no data available on the identity of the specific isomers of that compound in these species).

Cluster analysis of Bombus and Psithyrus species

The difference between the two dendrograms (Figs. 1-2) arises from the distinction between either the various isomers of hexadecen-1-ol (Fig. 2) or their absence (Fig. 1), as stated above.

The most striking conclusion to be derived from both dendrograms is that the species of both genera, Bombus and Psithyrus, appear «mixed », in strong 
opposition to other phenograms such as those based upon enzymatic constitution (Pekrarinen et al., 1979 ; Pamilo et al., 1981 ; Obrecht and Scholl, 1981) or wing venation (Plowright and STEPhen, 1973). Thus the marking secretions studied in this work seem to reflect a selection of Psithyrus for similarity to Bombus in order to improve their ability for parasitization, rather than phyletic relationships between both genera. For instance Psithyrus rupestris, which is known to parasitize Bombus lapidarius, appears in dendrogram 2 (Fig. 2) to be very close to this species. Such a kind of "proximity » is in agreement with the observations made by Cederberg (1979) who found that $P$. rupestris recognized the specific marking secretion of its host, B. lapidarius.

\section{Cluster analysis of Bombus species}

In the sample studied, the two great groups into which the genus Bombus is currently divided, i.e. Odontobombus and Anodontobombus appear to be well separated in both dendrograms, with only minor inconsistencies ( $B$. lapidarius in dendrogram 4 , and $B$. agrorum in dendrogram 3 ).

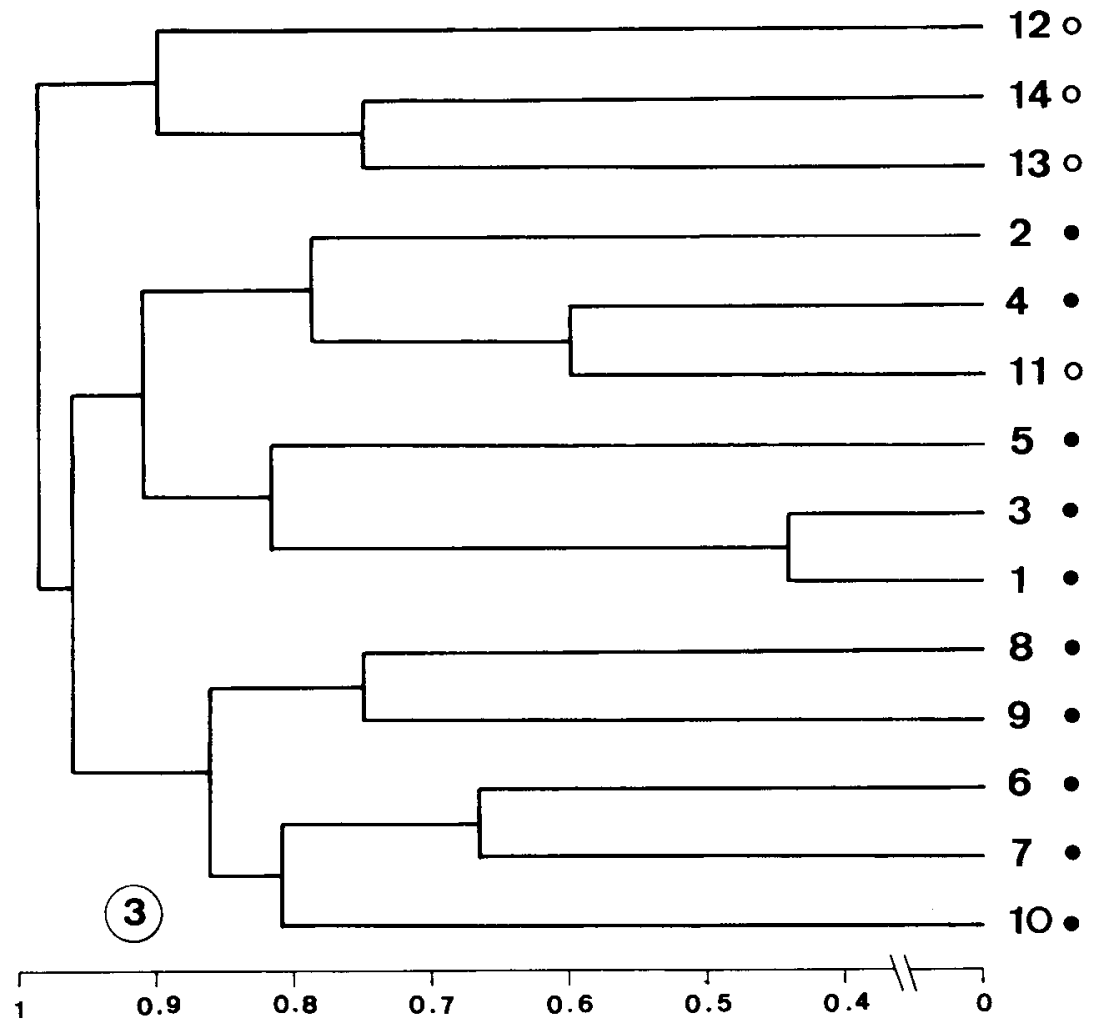

Fig. 3. - Dendrogram obtained for Bombus species.

Those belonging to the Anodontobombus section are indicated by black circles and those of Odontobombus by open circles.

(See the code number corresponding to each species in table 1). 


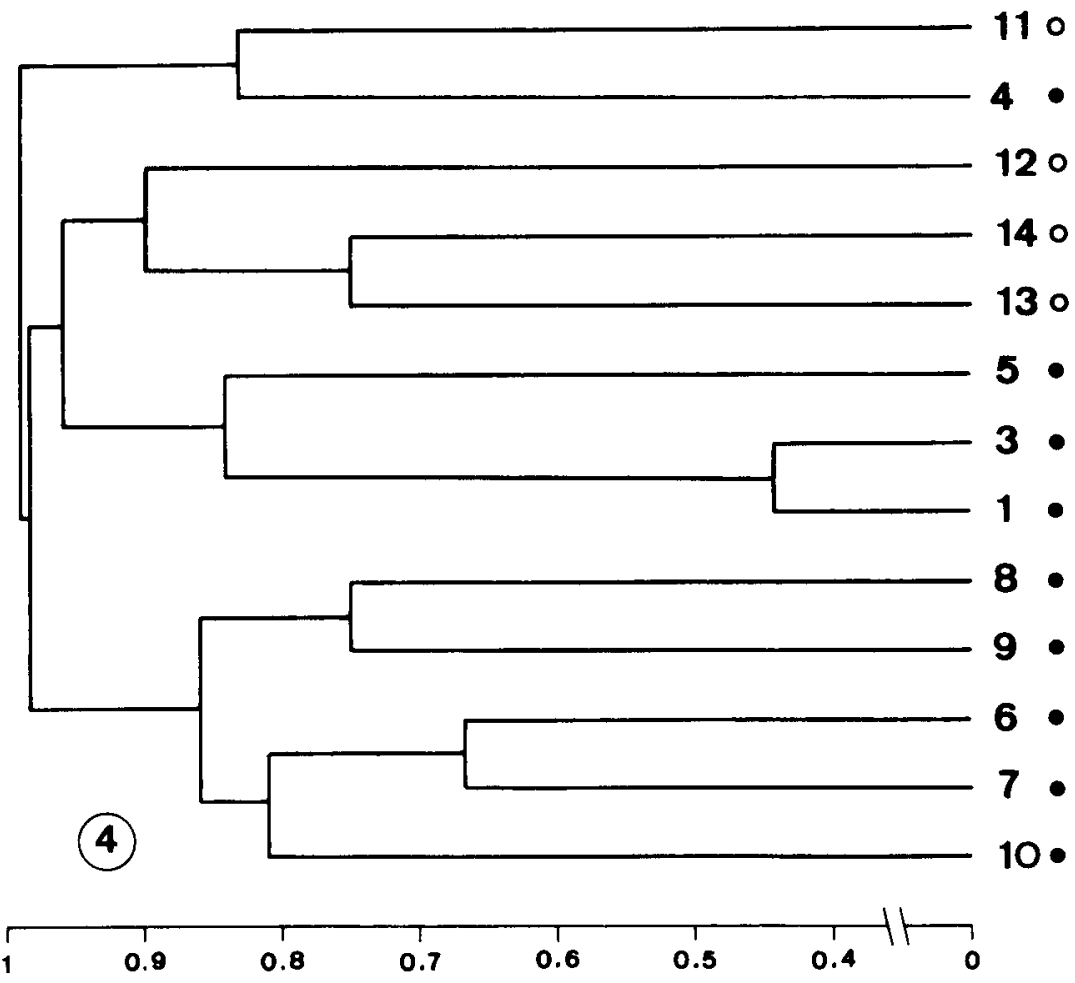

FIG. 4. - Dendrogram obtained for Bombus species considering the various isomers of hexadecen-1-ol.

(Abbreviations as in figure 3. Bombus hypnorum (2) has been omitted since there is no data available

on the identity of the specific isomers of that compound in this species).

Where subgeneric divisions are concerned, the separation achieved is less clean. Bombus agrorum and B. muscorum, which belong to the same subgenus, Thoracobombus, appear quite separate in both dendrograms. The same inconsistency is found in the case of Bombus (Pyrobombus) hypnorum and $B$. $(P$.) pratorum, although the subgenus Pyrobombus, in spite of its apparently homogeneous morphology, shows a notable heterogeneity as demonstrated in studies concerning allozyme constitution (PekKarinen et al., . 1979), numerical taxonomic analysis of wing venation (Plowright and Stephen, 1973) and mouth-part morphometrics (MEDL.ER, 1962).

Nevertheless, all the species of Bombus s. str. studied (patagiatus, sporadicus, terrestris and both * dark " and "blonde" forms of lucorum) coincide at the same cluster in both dendrograms, and even the grouping at species level is also satisfactory. This result agrees with the generalized view that considers these species as very closely related and clearly isolated from 
other congeneric groups, and which even have been combined under a separate subgenus Terrestribombus Vogt ( $c f$. RichardS, 1968 ; BergStröm et al., 1973).

Received for publication in June 1986. Acceptéd for publication in March 1987.

\title{
ACKNOWLEDGEMENTS
}

We are indebted to Professors M.S. BLum and F. CAMPs for their critical reading of the manuscript.

\author{
RÉSUMÉ \\ POTENTIEL TAXONOMIQUE DES CONSTITUANTS CHIMIQUES \\ DES SÉCRÉTIONS CÉPHALIQUES DE MARQUAGE DES ESPËCES \\ DE BOMBUS ET DE PSITHYRUS : ETUDE DE TAXONOMIE NUMÉRIQUE
}

On a étudié par la taxonomic numérique le potenticl chimiotaxonomique des sécrétions céphaliques de marquage chez les espèces de Bombus et de Psithyrus. On a utilisé la "weighted pair-group clustering method » (SoKal and SNEATH, 1973) comme technique de taxonomie numérique. Trente et un composés chimiques isolés à partir de ces sécrétions et précédemment mentionnés par d'autres auteurs ont été pris comme caractères taxonomiques pour un échantillon de 13 espèces de Bombus et de 6 espèces de Psithyrus (Tabl. 1 et 2). Les espèces de Bombus étudiées sont : cullumanus Kirby, hypnorum (Linnaeus), pratorum (Linnacus), lapidarius (Linnacus), soroeensis (Fabricius), lucorum (Linnaeus) (y compris les deux formes «foncéc » ct «blonde »), patagiatus (Nylander), sporadicus (Nylander), terrestris (Linnaeus), agrorum (Fabricius), muscorum (Linnaeus), hortorum (Linnaeus) et subterraneus (Linnaeus). Les espèces de Psithyrus sont : barbutellus (Kirby), bohemicus (Seidl), campestris (Panzer), globosus (Eversman), rupestris (Fabricius) et sylvestris (Lepeletier).

Des dendrogrammes ont été calculés pour l'ensemble de l'échantillon et pour les espèces de bourdons seules (Fig. 1 et 2). La conclusion la plus frappante est que les espèces des deux genres, Bombus et Psithyrus, apparaissent mćlangécs. Lcs résultats semblent done indiquer une sélection des psithyres favorisant la ressemblance avec les bourdons, pour améliorer leur capacité à les parasiter, plutôt que des relations phylétiques entre les deux genres.

Les dendrogrammes des espèces de bourdons montrent une discrimination très nette entre les deux groupes classiques Odontobombus et Anodontobombus (Fig. 3 et 4). On a trouvé de petites incohérences dans les sous-genres Pyrobombus et Thoracobombus en ce qui concerne- la séparation au niveau spécifique. Par contre toutes les espèces de Bombus s.str. (groupc Terrestribombus) semblent être bien classćes selon la classification taxonomique usuclle.

ZUSAMMENFASSUNG

DIE LEISTUNGSFÄHIGKEFT DER CHEMISCHEN BESTANDTEILE DER MARKIERUNGSSEKRETE AUS DEN KOPFDRÜSEN VON BOMBUSUND PSITHYRUS-ARTEN (HYMENOPTERA, APIDAE) IN DER TAXONOMIE : EINE NUMERISCH-TAXONOMISCHE STUDIE

Es wird von ciner versuchsweisen numerisch-taxonomischen Studie über die chemo-taxonomische Leistungsfähigkeit der Markicrungssekrete aus den Kopfdrüsen von Bombus- und Psithyrus-Arten, berichtet. Als numerisch-taxonomische Technik wurde die gewichtete Paar-Gruppen-Methode benutzt. Als 
taxonomische Merkmale wurden 31 chemische Verbindungen eingesetzt, die in Arbeiten früherer Autoren aus diesen Sekreten isoliert worden waren. Das Probenmaterial bestand aus 13 Bombus-Arten und 6 Psithyrus-Arten (Tab. 1 und 2).

Von Bombus wurden folgende Arten untersucht : cullumanus (Kirby); hypnorum (Linnaeus) ; pratorum (Linnaeus) ; lapidarius (Linnaeus) ; soroeensis (Fabricius) ; lucorum (Linnaeus) (einschließlich die beiden Formen "dunkel» und "blond»); patagiatus (Nylander) ; sporadicus (Nylander) ; terrestris (Linnaeus) ; agrorum (Fabricius) ; muscorum (Linnaeus) ; hortorum (Linnaeus) und subterraneus (Linnaeus). Von Psithyrus waren es folgende Arten: barbutellus (Kirby); bohemicus (Seidl); campestris (Panzer) ; globosus (Eversman) ; rupestris (Fabricius) und sylvestris (Lepeletier).

Dendrogramme wurden für den ganzen Probenumfang und für die Bombus-Arten allein berechnet (Fig. 1 und 2). Das auffälligste Ergebnis der ersteren Analyse ist, daß die Arten beider Gattungen gemischt erschienen. Demnach geben diese Resultate offenbar eher eine Selektion von Psithyrus auf Grund ihrer Ähnlichkeit mit Bombus wieder, die ihre Fähigkeit zur Parasitierung verbessern soll, als eine phyletische Beziehung zwischen beiden Gattungen.

Die Dendrogramme der Bombus-Arten zeigten eine klare Unterscheidung zwischen den beiden klassischen Sektionen Odontobombus und Anodontobombus (Fig. 3 und 4). Hinsichtlich der Trennung auf dem Niveau der Art wurden kleinere Widersprüche bei den Untergattungen Pyrobombus und Thoracobombus gefunden. Anderseits erschienen alle Arten von Bombus s.str. (Gruppe Terrestribombus) gut klassifiziert entsprechend der üblichen taxonomischen Anordnung.

\section{REFERENCES}

Bellés X., Galofré A., Ginebreda A., 1985. - Feromonas : relaciones entre estructura química y taxonomía. Un ejemplo de aplicación a algunas familias de Lepidópteros. Afinidad, 42, 147-157.

Bergström G., Kullenberg B., Ställberg-Stenhagen S., 1973. - Studies on natural odoriferous compounds. VII. Recognition of two forms of Bombus lucorum L. (Hymenoptera, Apidae) by analysis of the volatile marking sccretion from individual males. Chem. Scr., 4, 174-182.

Bergström G., Svensson B.G., 1973 a. - Studies on natural odoriferous compounds. VIII. Characteristic marking sccretions of the forms lapponicus and scandinavicus of Bombus lapponicus Fabr. (Hymenoptera, Apidae). Chem. Scr., 4, 231-238.

Bergström G., Svensson B.G., 1973 b. - 2,3- Dihydro-trans-farnesol : main component in the cephalic marking secretion of Bombus jonellus (Hymenoptera, Apidae) males. Zoon. suppl., 1, 61-65.

Bergström G., Svensson B.G., Appelgren M., Groth 1., 1981. - Complexity of Bumblebee Marking Pheromones : Biochemical, Ecological and Systematical Interpretations. In : Biosystematics of Social Insects, P.E. Howse and J.L. Clément eds., Academic Press, London and New York, pp. 175-183.

Buum M.S., 1981. - Sex Pheromones in Social Insects : Chemotaxonomic Potential. In : Biosystematics of Social Insects, P.E. Howse and J.L. Clement eds., Academic Press, London and New York, pp. 163-174.

Calam D.H., 1969. - Species and sex-specific compounds from the heads of male bumblebees (Bombus spp.). Nature, 221, 856-857.

Cenerberg B., 1979. - - Dofstyrt värdval hos snylthumlor. Entomol. Tidskr., 100, 128-129.

Cuadras C.M., 1981. - Métodos de Análisis Multivariante. Editorial Universitaria de Barcelona, Barcelona, pp. 431-474.

Frison T.H., 1927. - A contribution to our knowledge of the relationships of the Bremidae of America north of Mexico (Hymenoptera). Trans. Amer. Entomol. Soc., 53, 51-78.

KrügER E., 1917. - Zur Systematik der mittereuropäischen Hümmeln (Hymenoptera). Entomol. Mitt., 6, 55-66.

Kullenberg B., Bergström G., Ställberg-Stenhagen S., 1970. - Volatile components of the cephalic marking secretions of male bumblebees. Acta Chem. Scand., 24, 1481-1483. 
Medler J.T., 1962. - Morphometric analyses of bumblebee mouthparts. Proc. XIth Int. Congr. Entomol., 2, 517-521.

Orrecht E., Scholl A., 1981. - Enzymelektrophoretische Untersuchungen zur Analyse der Verwandtschaftsgrade zwischen Hummel und Schmarotzerhummelarten (Apidae, Bombini). Apidologie, 12, 257-268.

Pamilo P., Pekkarinen A., Varvio-Aho S.L., 1981. - Phylogenetic Relationships and the Origin of Social Parasitism in Vespidae and in Bombus and Psithyrus as revealed by Enzyme Genes. In : Biosystematics of Social Insects, P.E. Howse and J.L. Clément eds., Academic Press, London and New York, pp. 37-48.

Pamilo P., Varvio-Aho S.L., Pekkarinen A., 1978. - Low enzyme gene variability in Hymenoptera as a consequence of haplodiploidy. Hereditas, 88, 93-99.

Pamilo P., Varvio-Aho S.L., Pekkarinen A., 1984. - Genetic variation in bumblebees (Bombus, Psithyrus) and putative sibling species of Bombus lucorum. Hereditas, 101, 245-251.

PekKarinen A., 1979. - Morphometric, colour and enzyme variation in bumblebees (Hymenoptera, Apidae, Bombus) in Fennoscandia and Denmark. Acta Zool. Fenn., 158, 1-60.

Pekkarinen A., Varvio-Aho S.L., Pamilo P., 1979. - Evolutionary relationships in northern European Bombus and Psithyrus species (Hymenoptera, Apidae) studied on the basis of allozymes. Ann. Entomol. Fenn., 45, 77-80.

Plowright R.C., Stephen W.P., 1973. - A numerical taxonomic analysis of the evolutionary relationships of Bombus and Psithyrus (Apidae, Hymenoptera). Can. Entomol, 105, 733-743.

Richards O.W., 1968. - The subgencric divisions of the genus Bombus Latreille (Hymenoptera, Apidae). Bull. Br. Mus. Nat. Hist., 22, 209-276.

Sokal R.R., Sneath P.H.A., 1973. - Numerical Taxonomy, Freeman \& Co., San Francisco.

SvensSon B.G., Bergström G., 1977. - Volatile marking secretion from the labial gland of the north European Pyrobombus D.T. males (Hymenoptera, Apidae). Insectes Sociaux, 24, 213-224.

Svensson B.G., Bergström G., 1979. - Marking pheromones of Alpinobombus males (Hymenoptera, Apoidea, Bombinae). J. Chem. Ecol., 5, 603-615. 